This item was submitted to Loughborough's Research Repository by the author.

Items in Figshare are protected by copyright, with all rights reserved, unless otherwise indicated.

\title{
Doing being an ordinary technology and social media user
}

\section{PLEASE CITE THE PUBLISHED VERSION}

https://doi.org/10.1016/j.langcom.2018.03.002

\section{PUBLISHER}

(c) Elsevier

\section{VERSION}

AM (Accepted Manuscript)

\section{PUBLISHER STATEMENT}

This paper was accepted for publication in the journal Language \& Communication and the definitive published version is available at https://doi.org/10.1016/j.langcom.2018.03.002.

\section{LICENCE}

CC BY-NC-ND 4.0

\section{REPOSITORY RECORD}

Robles, Jessica, Stephen M. DiDomenico, and Joshua Raclaw. 2018. "Doing Being an Ordinary Technology and Social Media User”. Loughborough University. https://hdl.handle.net/2134/33063. 
Doing Being an Ordinary Technology and Social Media User 


\begin{abstract}
This paper uses discourse and conversation analysis of naturally-occuring conversations to describe how participants construct themselves as "ordinary" users of communication technologies - devices such as mobile phones, their communicative affordances, and the mediated interaction they enable (e.g., access to online communication via social media platforms). The three practices analyzed are (1) managing motivations by downplaying interest and stake in using technology and participating in online activities; (2) calibrating quantities of one's time and involvement using social media; (3) identifying investments in social media use through categories and identities that position users as appropriate or inappropriate. These techniques comprise an accounting practice that accomplishes identity construction in service of situated social actions to manage the moral implications of communication technology use.
\end{abstract}

Keywords: accounts, social media, technology, discourse analysis, stance, identity 


\section{Introduction}

New communication technologies and their affordances, particularly smartphones and social media, are a frequent source of complaint in public discourse. From decrying the behavior of millennials to bemoaning the loss of genuine conversation, media often depict modern technology use as a new, and undesirable, "normal" (e.g., Beck, 2016; Roberts \& David, 2016). In actual face-to-face conversation, then, participants are faced with the dilemma of how to perform and construct their own technological conduct as unproblematic. After all, we are accountable for being anything other than "ordinary," where ordinary is the natural, taken-forgranted attitude that pervades and holds together the social world (Garfinkel, 1967). How then do people manage the potential reproachability of their conduct against this backdrop of recurrent public criticisms of how people use new communication technology?

This paper analyzes ordinary conversations to examine how the mundane yet meaningful features of social interaction are enrolled in socially constructing stances around talk about technology and social media use. Drawing on ethnomethodology and applying discourse analysis and aspects of conversation analysis, we focus on moments in which participants produce accounts that implicate norms of communication technology usage, specifically devices such as mobile phones and their communicative affordances (Gershon, 2017; see also: Hutchby, 2001), or the possibilities for mediated interaction that these devices enable (e.g., access to online communication via social media platforms). We draw on two complementary meanings of accounts, including the acountability interactants have to co-producing ordinary intelligible meaning (Garfinkel, 1967; Sack, 1984), as well as accounts as speech acts and social activities in which proffering and demanding accounts tends to occur moments in interaction where morality is at stake (Buttny, 1983). These are related concepts, since as Garfinkel (1967) showed with his breaching experiments, something that threatens the apparent normalness of day-to-day interaction (Garfinkel, 1967) will require an explanation. By examining when and 
why interactants offer accounts regarding such matters, we can therefore gain insight into the interactional, relational, and cultural assumptions that

interactants rarely articulate explicitly. Furthermore, we gain insight into how such assumptions shape how we engage with and rationalize technological aspects of social life.

We describe three interactional practices that work to present participants as "ordinary" users of communication technologies: (1) managing motivations for social media use, where participants downplay the interest and personal stakes they have in participating in online activities; (2) calibrating quantities of social media use, where participants reference one's time and involvement using social media; and (3) identifying investments in social media use, where participants deploy categories and identities that position their technology use as appropriate or inappropriate. Each of these practices comprises specific structures, features, and social actions through which participants sequentially accomplish "strategies" for doing being ordinary "about" their uses of new technologies and social media. Taken together, these practices comprise a larger accounting practice that accomplishes identity construction in service of situated social actions to manage the moral implications of communication technology use, providing insight into the "folk metalinguistics" (Taylor, 2016) of technological conduct. Our analysis of this practice shows how technology and social media use may be positioned as morally accountable, and how interactants construct their participation in these activities as "ordinary" to manage possible reproaches.

There is a tremendous body of research examining the psychological motivations, attitudes, and functions of engagement in online spaces and with social media, much of which correlates aspects of social media use with variables such as narcissism, extraversion, selfefficacy, support and belonging (e.g., Bargh \& McKenna, 2004; Gangadharbatla, 2008; Kramer \& Winter, 2008; Lu \& Hampton, 2017; Ong, et al., 2011). This paper takes an alternative approach by examining in detail how people in ordinary conversation spontaneously topicalize and evaluate use of technology and social media platforms, particularly with regard to their own and others' behavior. This research contributes to discussions of the ways that norms around new 
technology and social media use are constructed moment-to-moment through everyday social interaction.

Drawing on a corpus of more than 30 hours of naturally-occurring video-recorded conversation, we apply discourse and conversation analysis (Ehrlich \& Romaniuk, 2014) to detail how people jointly construct what it means to be an "ordinary" user of modern communication technology related to social media behavior. This work builds on our previous research, which examines situated uses of mobile phones in face-to-face interaction, to develop a more fine-grained perspective at how people display and co-create what "ordinary" comportment and identities regarding technology use are or should be, through conversational actions that explicitly discuss and assess people's stances toward moral implications of uses of social media platforms. The results highlight some of the ways in which participants use language and embodiment to accomplish mundane morality and locally build cultural and ideological stances toward technology and social media use as a relevant dimension of social life (Barker, 2008, Gershon, 2010). In the next section we discuss literature at the intersection of conversation and technology, followed by a discussion of our methods, analysis, and some reflections.

\section{Conversation and Technology}

When sociologist Harvey Sacks (1992) described in an opening lecture that his course would deal with "the technology of conversation" (p. 413), he could hardly have imagined the contested relationship the words "technology" and "conversation" would have with one another across public discourse a few decades later. Sacks used the word "technology" in a broad way, similar to the idea of a technique or practice: something with a defined use or for a particular function, for example, a membership categorization "device" in descriptions, which lumps certain sorts of people together and separates them out from others (Sacks, 1986). In the socalled "digital era," technology has become a shorthand for objects—-tangible and intangible_that have had the effect of massively changing our lives, whether by allowing us to cross huge distances in hours, or to see someone living in another country speak to us in real time (Herring, 2015). 
Nowhere have these changes been more visible, or publicly debated, than in the case of information communication technologies. Studies of information communication technologies (ICTs) have been especially lively among researchers in the last decade (e.g., D’Urso, 2009; Herring, 2015; Lievrouw \& Livingstone, 2001, 2006; Tidwell \& Walther, 2002; Walther, Gay \& Hancock, 2005). Social media has become a central feature at the nexus of communication and technology, implicating as it does the communication of messages, social interaction, technological advances, mediated discourse, and mobility (Herring, 2015; Lievrouw, 2014). Popular media has featured a number of voices in the public discourse lambasting or valorizing social media and its role in society (e.g., Hampton, 2012; Turkle, 2015b), generating various counterarguments (e.g., Oppenheimer, 2014); and research has highlighted its role in everything from business to education to protests (e.g., Bennett \& Segerberg, 2011; Hickerson \& Kothari, 2016; Kaplan \& Haenlein, 2010; Keitzmann, Hermkins, McCarthy \& Silvestre, 2011).

Other research seeks to understand how people themselves see the role of social media in their lives, usually through surveys, questionnaires, and interviews about self-reported beliefs and attitudes (e.g., Akar \& Topcu, 2011; Kennedy, Elgesem \& Miguel, 2015; Westerman, Daniel \& Bowman, 2016). However, over the past decade there has been an increasing stream of work that inspects how communication technologies such as smartphones and other mobile devices, and social media platforms, such as social networking and online dating sites, are made relevant to or unfold in particular ways in actual interaction (e.g., Arminen, 2005; Brown, McGregor \& McMillan, 2014; Haddington \& Rauniomaa, 2011; Laursen, 2012; Rivière, Licoppe, \& Morel, 2015). The affordances (Gibson, 1977; Lu \& Hampton, 2017) of new technologies and their impacts on everyday life (see boyd, 2010; Ling \& Baron, 2013) have consequences demonstrable in how they are used and talked about in everyday conversation, and these local practices build and reflect ideologies about their meaning in society (Thurlow \& Brown, 2003).

Tannen and Trester (2013) note that technologically-mediated discourse provides new insights into who we are and how we connect through language. The mobile phone, as a portable portal through which people access social media platforms (e.g., Lenhart, Ling, 
Campbell \& Purcell, 2010), also has a history of generating, shaping, and drawing attention to social norms about what sorts of behavior are appropriate (Humphreys, 2005; Ling, 2004).

Thus, a focus on how people engage with these devices and platforms in ordinary conversation allows us to track displays of opinions and ideologies at the intersection of technology, social media, and language, as these are built through stances that unfold during situated social actions (Arminen, Licoppe \& Spagnolli, 2016).

As interactants challenge and assess one another and non-present others' technology and social media conduct, they also work to position themselves in relation to ordinary and acceptable versus problematic and accountable behavior. Impression management--how people manage others' perceptions of them--has emerged as a key area of interest across researchers of new technology and social media, and in studies comparing possible gender and cultural differences and drawing on qualitative and ethnographic data (e.g., Herring \& Kapidzic, 2015; Jung, Youn \& McClung, 2007; Ling \& Yttri, 1999; Pearce \& Vitak, 2015). ${ }^{11}$ Research examining the integration of new technology and social media into social interaction has not typically drawn on this concept, though discourse analysts have examined how relational and phatic dimensions of communication are produced (or not) in these spaces (Ling, 2004; Rampton, 2015; Wargo, 2010; see also Licoppe, Riviere \& Morel, 2015); and more critically-oriented discourse analyses have examined the production of self through social media use in relation to societal and cultural assumptions (e.g., Tiidenberg, 2014; Tiidenberg \& Gómez Cruz, 2015). Yet these studies do not emphasize a more fine-grained approach to documenting the communication practices through which impression management is enacted in contexts where technology is relevant. Accounts, which are descriptive or explanatory actions that may also be used to manage potentially problematic attributions (Buttny, 1993), offer insights into how people perform stances (Jaffe, 2009) (what might otherwise be called opinions or attitudes ) toward social behavior, and what

\footnotetext{
${ }^{1}$ Hogan (2010) points out that an important difference between impression management (as described by Goffman: 1959, 1967) in social situations and how it takes place online involves the online environment's mediation architecture and interactional constraints (i.e., asynchrony), proposing that social media presentations of self should be considered more an exhibition hosted by an online curator than a drama (as Goffman conceived of impression management).
} 
counts as good or appropriate versus bad or reproachable behavior.

Sacks (1984) described how "being ordinary" is an accomplishment, building on

Garfinkel's (1967) ethnomethodological interrogation of how people practically build everyday life. "Ordinary" is not often thought of as being "good" (contrastable with "bad") but Garfinkel showed that ordinariness is absolutely moralized, such that threatening it incurs immediate negative consequences. Jefferson (2004) developed this specifically in relation to stories: participants begin by positioning themselves as "ordinary," "normal," just going about their business, not looking for trouble or leaping to the first wild interpretation; this, then, is the staging for them to relate some extraordinary event. We notice similar work being done in our data: certain behaviors around communication technologies are treated as potentially extraordinary. The ordinary is what Garfinkel (1967) was describing as the morality that pervades interaction, and for which we are all accountable: the mundane, invisible work of holding the world together for practical purposes. Violations demand explanations, justifications, and so forth: accounts can be used to mend a trouble that has been created (Buttny, 1993). But whether accounts are simply producing intelligibility, or serving a more "face-saving" function (Goffman, 1967) in response to a trouble, they are a sort of sensemaking practice that produces people as “ordinary" (Sacks, 1989)--and sometimes, as we will show, this is expected because ordinariness may come into question.

Because communication and technology in general—and social media in particularinvolve linguistic and embodied aspects of interpersonal interaction and mass media (Lievrouw, Bucy, Finn, Frindte, Gershon, Haythornthwaite, et al., 2001), our project can be seen as attending to both the interpersonal dimensions of language use in how people interact face-to-face, and media effects regarding the ways different media forms are received and interpreted. To do this, we examine how people formulate and present attitudes--stances--toward norms of social media use in situated moments of social interaction. In the following section, we explain our methods for carrying this project forward.

\section{Methods}


The ubiquity of new technologies, their communicative affordances, and their mobility as portable devices (see Humphreys, 2010; Laurier, Brown \& McGregor, 2016; Lenhart, Ling, Campbell \& Purcell, 2010; Ling \& Haddon, 2001) makes electronic media and mediated interaction a ready-to-hand resource in social interaction. Thus, we examine situated practices through which participants construct "ordinary," unproblematic uses of communication technologies and social media thus locally producing norms for these forms of social behavior.

Our approach is informed by ethnomethodology (Garfinkel, 1967) in terms of examining participants' methods for producing intelligible conduct for the accomplishment of practical social action with others, and how the accountability people have for doing so may be normatively sanctioned where it fails. We also take a discourse perspective (Jaworski \& Coupland, 2014) that understands "discourse" as comprising the verbal, nonverbal and embodied action through which people coordinate their activities (consistent with multimodal and embodied approaches to interaction). Discourse analysis, generically speaking, is any analysis of discourse as "language-in-use," in the context of its production (Cameron, 2001; Potter, 2003). We attend particularly to communication-based discourse analytic traditions that are interested in the pragmatics of communicative acts, their implications for constructing identities, and their treatment of action as strategic and goal-oriented (Tracy, 2001). However, we also draw substantially on conversation analytic procedures that ground "goals" in the projectability of social action, and analyze how actions are sequentially organized turn-by-turn (Ehrlich \& Romaniuk 2014; Schegloff, 2007). Pulling these methods together allows us to examine how certain content is topicalized, but to ground these matters in participants' demonstrable orientations to how content is procedurally relevant.

This paper comes out of a collaborative project examining how people use and talk about norms of technology use and mediated communication. Our corpora of 15 hours of naturallyoccurring interaction video-recorded between 2004 and 2014 across six states in the U.S.A. were were collected by all three authors in accordance with their respective university ethics guidelines. Adult (at least 18 years of age) participants were recruited by word of mouth or 
classroom announcement. Participants were recruited to record ordinary conversation for examining various aspects of social interaction; they were not recruited to examine a specific phenomenon or to represent a particular population, as this sampling standard is at odds with the research paradigm of discourse and conversation analysis (see Jaworski \& Coupland, 2014). Those who volunteered to participate were provided consent forms in which they selected precisely how their data could be used, including uses of audio, video, and images, as well as whether this was permissible in outlets such as classroom exercises, academic conferences, and scholarly publications. All participants have been given pseudonyms, and specific details that might reveal their identity (e.g. references to locations) have been obscured or deleted from transcripts. Participants were all provided information about the research, which explained the purpose of data collection, and emphasized that they could withdraw or change details of their consent at any time.

From our corpus, for our larger research project, we had collected 112 sections of recordings in which participants interacted with technological devices (smartphones, laptops) and/or topicalized such devices or their uses in talk. For this analysis, we selected 41 instances in which participants talked about one another's or non-present others' technology or social media use, and then 20 in which such talk was directed toward specific people or sorts of people in negative assessments; these were transcribed according to the Jefferson (1984) style to capture interactional features beyond the mere content of talk, including pacing, overlap, emphasis, and so forth; and were analyzed using discourse and conversation analysis analysis (Ehrlich \& Romaniuk, 2014) to inspect how the mundane yet meaningful features of social interaction are enrolled in socially constructing stances around talk about social media use. The seven illustrative excerpts selected for this paper highlight the particular features across the set we examined, and all come from recordings obtained 2011-2012. Where images appear, these conform to participants' consent as explained in the previous paragraph. In the next section we discuss some findings about how people construct ordinary social media use in face-to-face social interactions. 


\section{Analysis}

In this section we present analyses of three discursive practices participants in the data used to construct an average, ordinary, or "normal" idea of a social media user:

1. Managing motivations: participants worked to present neutral, uninterested stances toward social media, removing agency in reconstructing their activities therein and presenting themselves as passive participants. The central challenge for participants is why they are using social media in particular ways, and the aim is to not seem overly invested or interested in it, to have a low stake in the matter.

2. Calibrating quantities: participants used quantities and attempts to measure or count time, involvement, or instances in order to present apparently-objective "facts" that further proved their social media use to be ordinary and unremarkable in service of focusing on the local action underway (which was rarely "about" the social media as a topic itself). The central challenge for participants is how they are involving themselves in social media, and the aim is to manage "how much" social media impacts their life.

3. Identifying investments: participants formulated or attributed categories and identities to selves and others that sought to label behavior as appropriate or inappropriate and thus assess and moralize what counts as reasonable actions. The central challenge for participants is who they present themselves to be when using social media, and the aim is to negotiate a "normal" character for themselves.

Each of these practices are accomplished sequentially through specific actions and features of talk, including advice-seeking, assessments, stories, turn construction, categories and references, and so forth; and through these practices, participants built stances toward communication technologies by accounting for their own "ordinary" usage, and questioning and challenging that of others. Thus, they produce accounts in the form of stories, descriptions, and so forth, that re-render their behavior as ordinary in the context of possibly 
seeming strange in some way. The analysis show how participants may orient to communication technologies (especially social media) as relevant windows into others' identities and as resources for locally and culturally constructing the morality of selves and others.

\subsection{Managing Motivations}

A key resource through which participants worked to normalize their technology-related conduct was by carefully managing interpretations of their motives behind social media use. When introducing these matters as topics in their conversations, participants worked to emphasize the ordinariness of their behavior. In order to do so, they used story beginnings and descriptions that presented a natural, neutral stance toward the topicalized item. For example, in Excerpt 1 three young women - May, Lila and Em (see image 1) - talk about how Em has not changed her phone case (line 1) before discussing May's use of her mobile phone to take "selfies" (self-taken photographs of oneself). In the segment below, Lila launches a complaint about May’s apparently-deliberate disruption of her attempts to take "selfies."

\section{Excerpt 1 "Juggle my phone"}

1
2
3
4
5
6
7
8
9
10
11
12
13
14
15
16
17
18
19

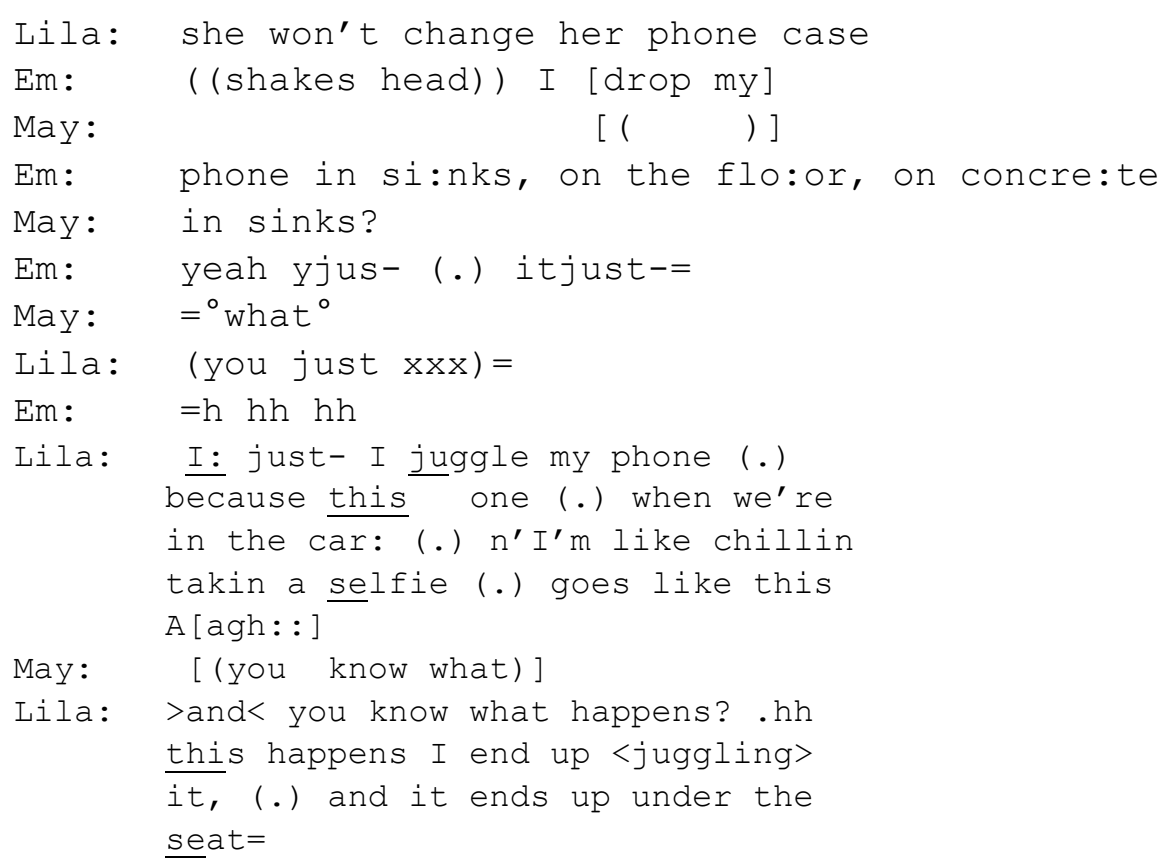

Prior to this exchange, Lila had been teasing Em on Em's careless treatment of her phone, which Em aligns with by confirming that in addition to not changing her phone case, she also typically 
drops her phone in odd places (line 4). Though in some sense this constructs Em as less interested in or connected to her phone, May's "in sinks?" (line 5) could be challenging that presentation of self, suggesting that having a phone in-hand at a sink is odd. This talk leads onto Lila's storytelling about her own "phone dropping" incident, but in response to May's behavior. Lila uses her phone, and her body, to reconstruct and narrate her use of her phone during trips in the car as ordinary and unproblematic: her reported actions in lines 16-19 are described as being complicated by May's actions rather than causing them, and her uses in lines 10 and 12 of "just," and the slang term "chillin," suggest a relaxed, "normal," not-needing-an-account way of being (Carbaugh, Berry, \& Nurmikari-Berry, 2006). "Chillin" is produced with an embodied enactment of taking a selfie that presents it as a casual action, void of any "preening" or fanfare, in which Lila just briefly flings her hand up as if holding her smartphone up to take a photograph (image 1). This embodied performance of Lila's presentedly unproblematic behavior for her interlocutors reconstructs what she proposes was her conduct at that prior time.

\section{Image 1: “Chillin" Line 12, From left to right: May, Lila, Em}

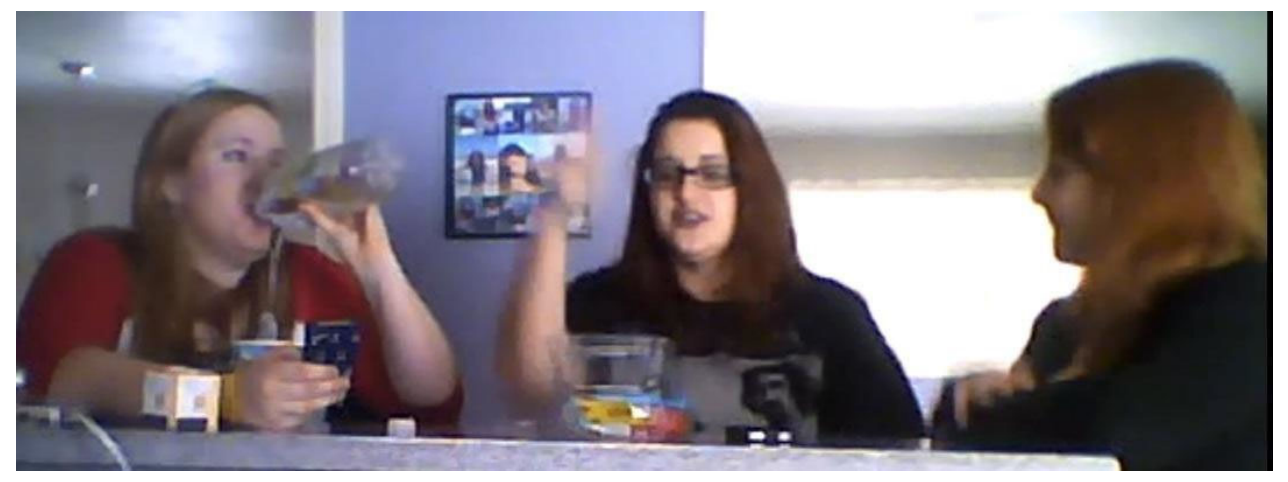

Instead, the problematic action being narrated is May's disruption that led to Lila dropping her phone. This is contrastively narrated with a dramatic reenactment of May's deliberate disruption of Lila's activity, and the effect it has of causing her to "juggle" her phone, as seen in images 2 and 3. At "this" (line 17) Lila even picks up her phone in order to visibly juggle it in the air over her head. 

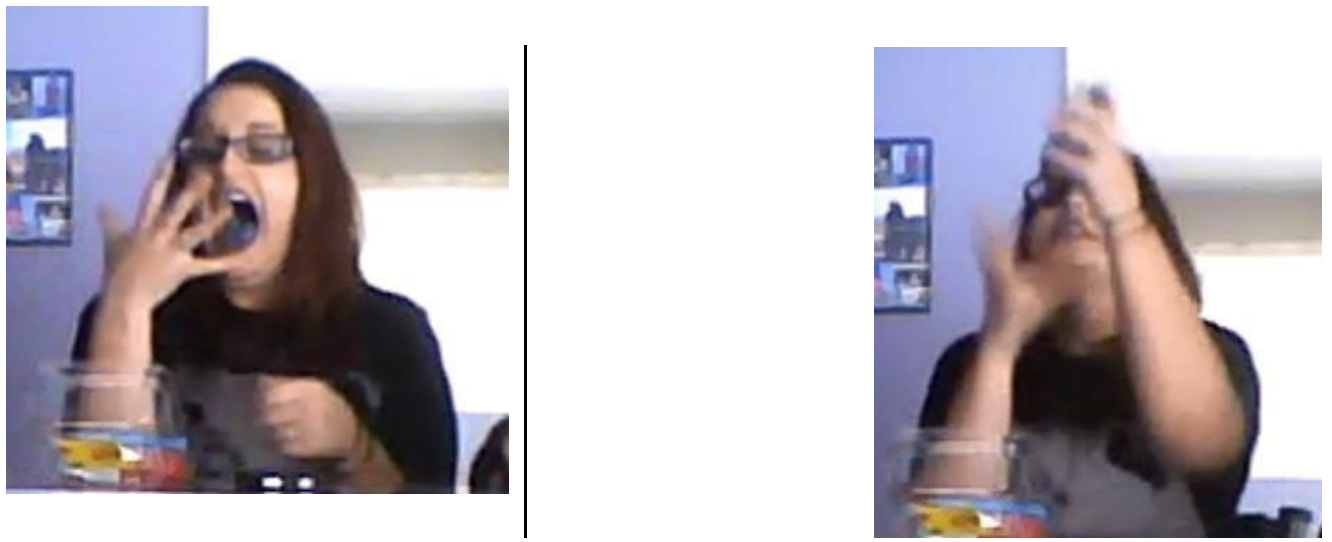

The episode unfolds as an "I was minding my own business" set-up to complain (Selting, 2010) about another's behavior (Jefferson, 2004), and it functions as a sort of disclaimer against possible accusation of having "asked for trouble" while "doing being ordinary" (Sacks, 1984). All the data in our collection, and discussed herein, reflect this orientation to "being ordinary" versus involved in some sort of trouble (though not all excerpts feature explicit formulations like “just chillin.” in Excerpt 1).

The next example includes participants talking more explicitly about social media use. In Excerpt 2, Blake initiates a storytelling about his roommate setting up an online dating account for him without his permission. He is in a group of young man all sitting around on a couch (though Blake is in a chair), leaning back, drinking beer, and not doing anything in particular when Blake launches his description.

\section{Excerpt 2 "Whadda ya think about online dating"}

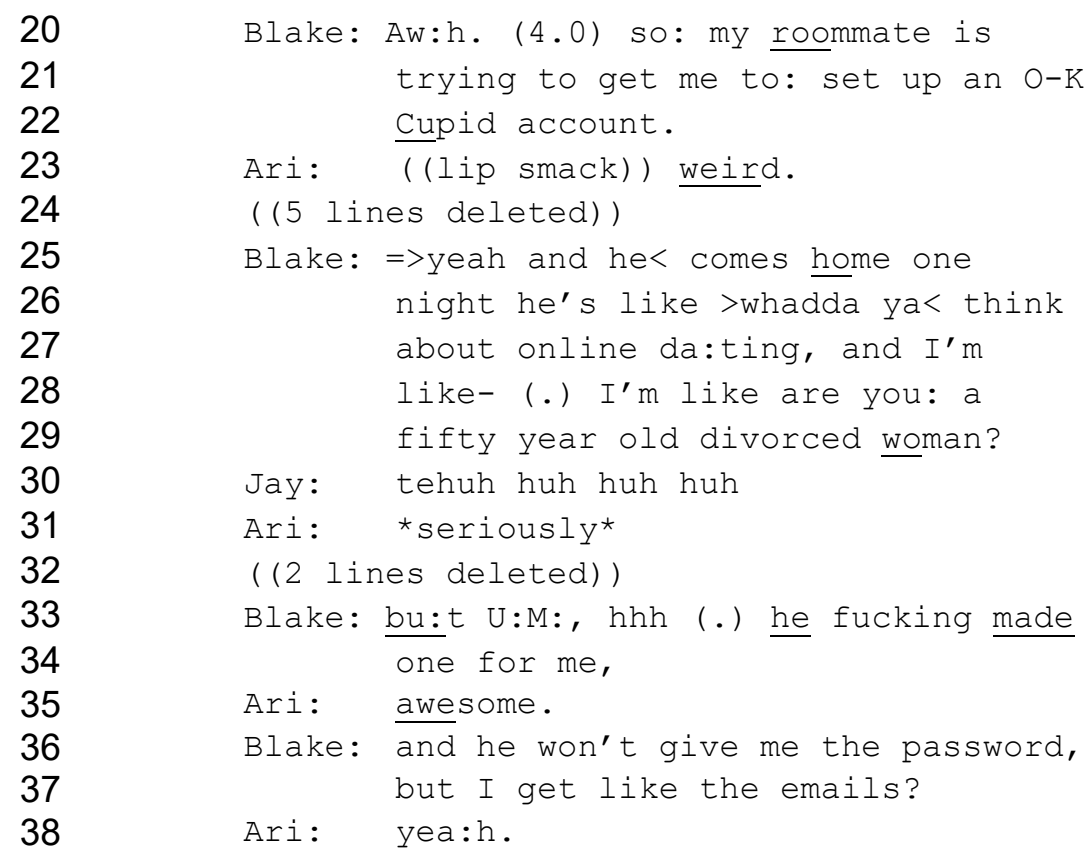


39

40

41

42

43

44

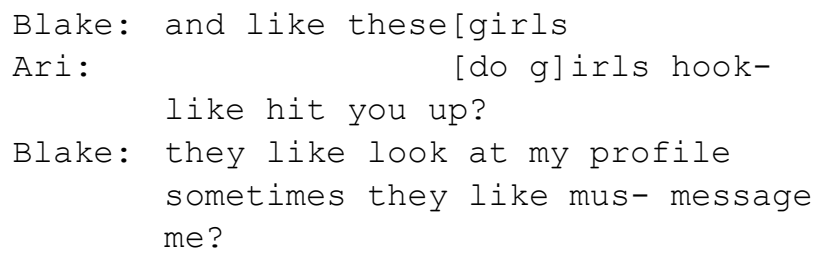

While portraying his own stance as neutral, normal, and uninterested, Blake also orients more explicitly to the accountability of the activity of online dating. That this is possibly necessary is evinced by aligning responses such as "weird," "seriously," "yeah," and laughter (e.g., lines $23,30,31,38)$.

Thus, Blake works to downplay his own agency in the activity, framing it as entirely separate from himself. He initiates the story as if to project into the future in lines 20-22, but follows in lines 25-29 with reported speech (Gordon, 2006) as though it were merely a prior conversational topic. Blake's reported reply to his roommate's question is in the form of a rhetorical question (which may or may not have been voiced) that casts what is presented as an imaginary typical person who sets up an online dating profile: "50 years old," "divorced," and "woman," all categories that contrast sharply with those of the participants (young, single, male)/ Ari and Jay also align with Blake's stance via affirming laughter (e.g., line 30).

Later in Blake's telling, Blake reveals that an online dating profile has already been created for him, by his roommate, without his permission and without providing him with the password necessary to delete or make changes to the profile himself. All of these formulations in Blake's storytelling present him as a passive recipient of, rather than an active participant in, online dating. Subsequent descriptions describe him, even further, as a passive recipient of the attention of women who view his profile (lines 36-44). Ari seems to respond in a somewhat ironically-positive way with a positive assessment, affirmation, and request for information that would imply that women have pursued Blake (lines 40-41). Thus, it is ambiguous for some portion of the exchange whether Blake's friends treat his story as a complaint or some news announcement. They certainly do not orient to his story as requiring strongly-aligning responses--even their bodily comportment does not shift, and their own personal attentions to their mobile phones or beers are not altered. 
But rather than (or in addition to) a complaint about something that could happen or has happened, these stories also position Blake as someone who may be seeking advice (see Goldsmith \& Fitch, 1997) about how to respond to the emails (which is further complicated by his display of a neutral stance towards the matter). In sum, Blake's telling and larger complaint about his roommate setting up an online dating profile is part of a larger course of action regarding advice seeking (see Jefferson, 1988). By emphasizing his lack of agency in setting up the online profile, Blake could be seen as preparing a complaint, but seems also to attempt to quickly move past the matter of setting up the account in order to get to the possibility of replying to a woman's message (though, as will be discussed later in this analysis, it appears to be unsuccessful).

In these first two examples, technology use is topicalized in ways that characterize participants' behavior as ordinary while acknowledging, or at least orienting to, their possible accountability in terms of "ordinary" everyday usage. It is the content of the talk--its relationship to a particular domain of life--that is treated as either some impediment or reason for an action. At inception, the participants move to get the technology itself "off the table" to focus on the main actions underway_for example, complaining and seeking advice. By downplaying one's motivation or agency with regard to using these technologies, participants use specific actions and resources to display both local and cultural stances that are designedly ordinary and meant to side-step unwanted comment, criticism, or attention; such practices may also "test the waters" as to whether behavior will be received as normal or not. In the first excerpt, the activity itself is treated as ordinary, while in the second, the activity is treated as strange, requiring the self to have been pulled into it (almost against one's will) in order for the self to remain ordinary.

In the process of launching activities in and through talk, sometimes participants get a bit tied up in particulars that threaten to reveal accountable stakes participants have; in other words, their involvements may reveal details that become challenges to their presentation of passivity and ordinariness. To maintain a neutral, distant, "normal" stance, participants must manage the motivations or reasons why they have use new communication technologies and social media. In 
the next section, we describe one way participants deal with this threat by carefully tracking what is deemed an acceptable degree of usage of a particular communication technology.

\subsection{Calibrating Quantities}

If the motivated dimension of one's stance is a qualitative sort of description, in this section we deal with a more quantitative one, in which participants deal with apparently "objective" (Potter \& Hepburn, 2007) materials that crop up as relevant in their descriptions. The amounts and extents of technology usage have implications for participants' stake in an issue-the extent to which they are motivated and care about something going on and in which their identity may be implicated--so they may attempt to "measure" their usage in such a way as to emphasize its unremarkableness to combat potential accountability. For example in the next segment that follows on from Excerpt 1, Lila has been teased about how many selfies she takes during a typical drive (jokingly described as "like 20") as well as how often she posts those selfies on the social media platform, Instagram (she claims to have "like four" selfies on Instagram).

\section{Excerpt 3 "That's a lot like four"}

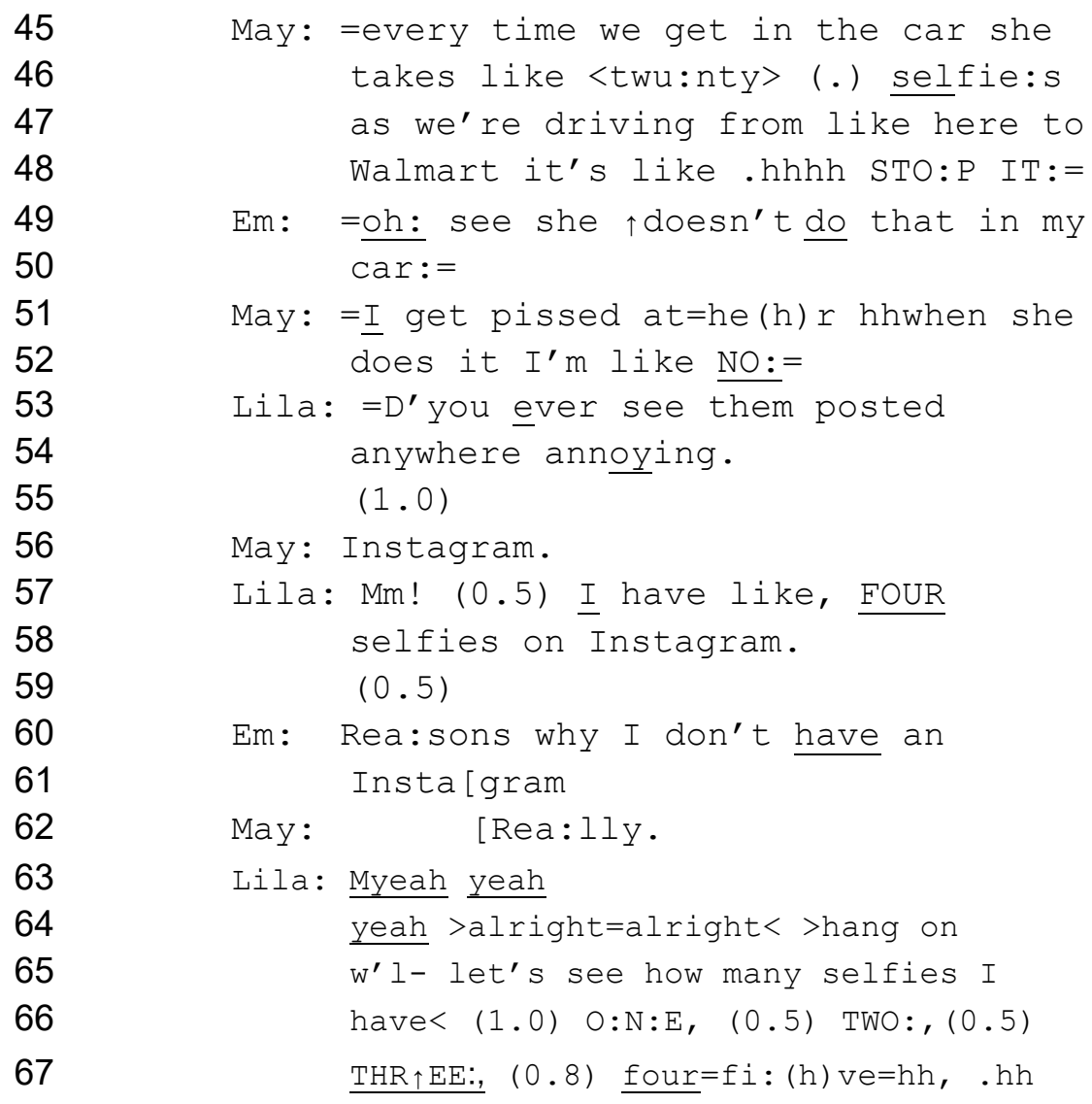




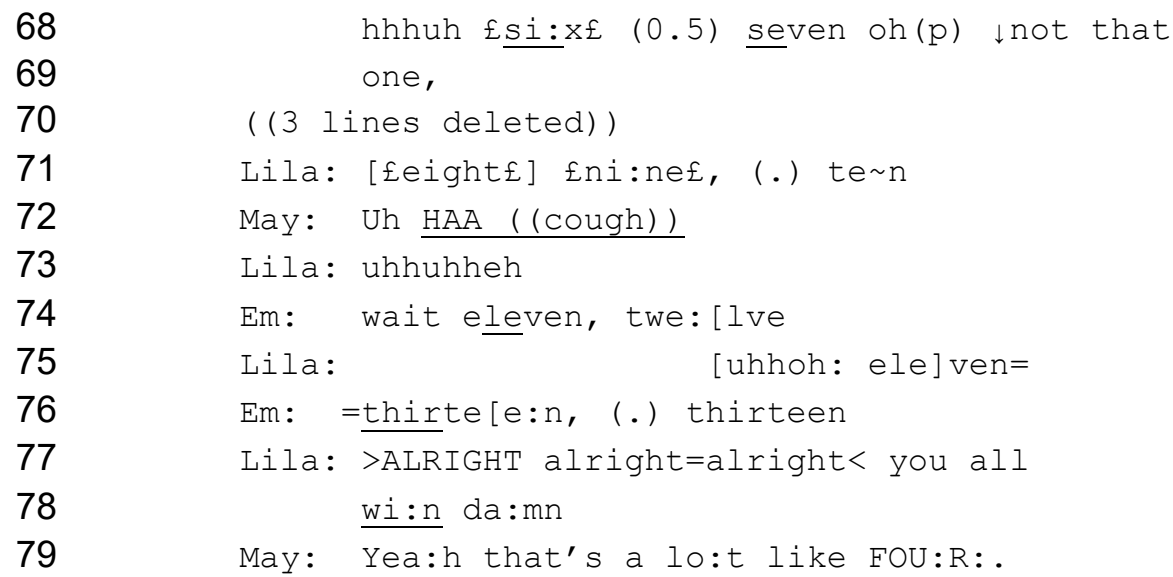

Excerpt 3 (continuing from the conversation about how May disrupts Lila's selfie-taking, Extract 1), there is an explicitly numerical negotiation about how many selfies Lila posts and what constitutes "too many." This begins with May's assertion of what is described as an inappropriate number of selfies to take during a drive to Walmart (lines 45-48). This is presented as extraordinary by implication of the mundane nature of the event (driving to a department store) and possibly the distance (which may not be far in relation to the number of selfies accomplished in the interim). May presents this as a complainable activity (therefore justifying the disruptive behavior portrayed in Excerpt 1). Lila's counter in lines 53-54 is to move the topic from her situated engagement with a technological device, to her use of the material produced (the selfies) on social media. She acts out this activity, embodying her ordinary, uncomplainable behavior. Thus, she acknowledges that she may take a lot of selfies, but proposes this is not problematic because they are not posted anywhere "annoying" (line 54). Here the adjective "annoying" implicitly modifies her mention of (social media) platform ("anywhere") rather than the content or manner in which the selfies are posted; however, it could be that describing the platform as annoying implicates the other elements of the selfies' appearance thereon (in a metonymic fashion).

May, however, offers a candidate "annoying" platform in line 56: Instagram, a social media site on which people primarily post photographic content. Lila, then, proposes a downgrade to the possible annoyingness in the form of an approximate numerical description, "like four selfies," implying this is a reasonable number (lines 57-58). Lila then initiates "proof" 
of her claim that her social media behavior is ordinary by using her mobile device to scroll through her Instagram account with another participant, Em, looking for "selfies." She reaches for her phone at the "Mm!" on line 57 and has her phone raised with the screen facing her as she says "four" on line 57 (see image 5). By May's "really" on line 62, Lila has lowered the phone slightly and is scrolling, apparently through her Instagram photos (image 6)

\section{Image 5 "Like four" Line 57}

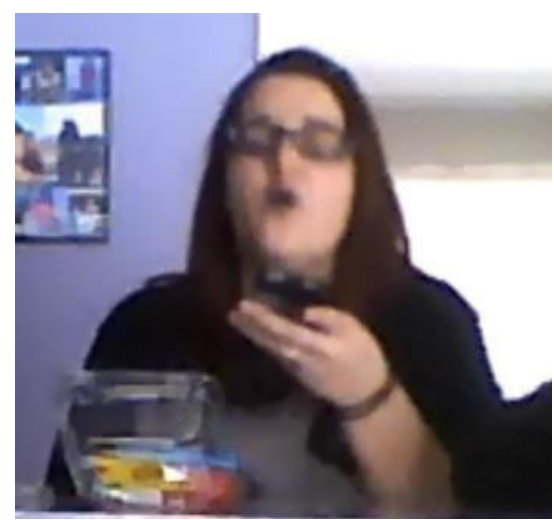

\section{Image 6 "Really" Line 62}

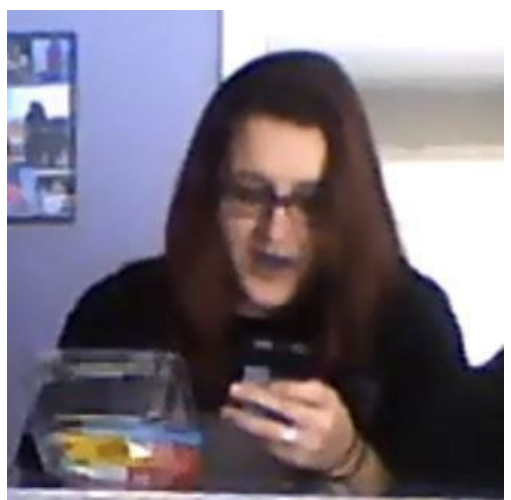

At the onset of the one-second pause on line 66 after Lila initiates the selfie-search with "let's see" (framing it as a sort of recruitment), Em leans in so that she is also in position to see the screen of Lila's phone (see image 7).

Image 7 “(1.0)” Line 66

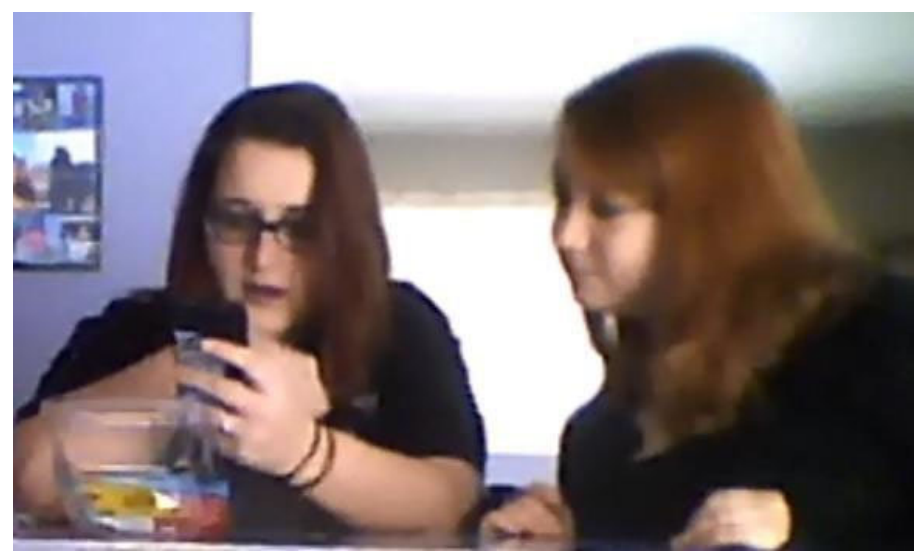

Lila and Em both count up the instances of selfies together, with increasing smile voice and laughter particles as the number increases beyond the original estimate of "like four." Lila initiates the "count" and there is a rush-through from four to five and some laughter particles in five as well as smiling from both, suggesting this is a turning point (between Lila's guess of "four," and more than four) (see image 8). 


\section{Image 8 "Four-five" Line 67}

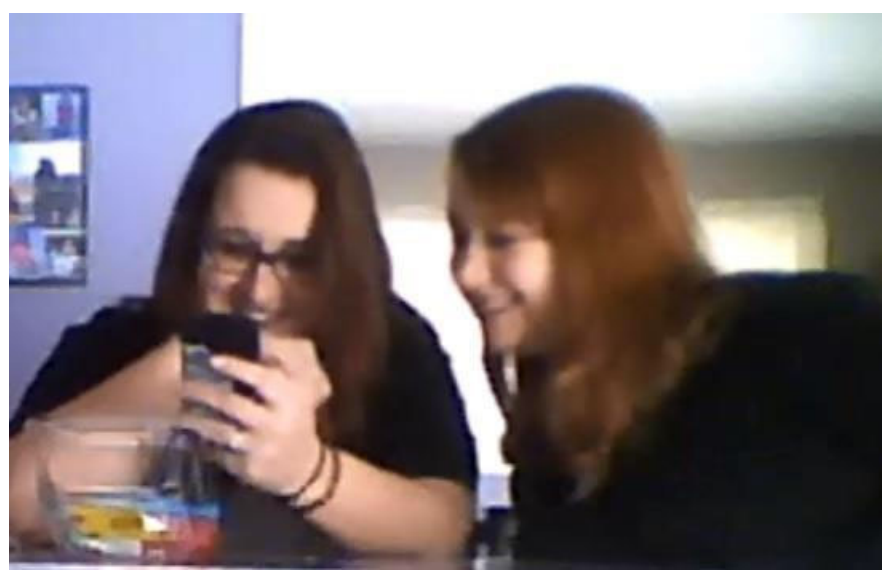

That the number "six" provides another possible shift in significance is hearable by the laughter preceding and the smile voice produced around reaching the number "six" in line 68. Smile voice is present around eight and nine, which are produced without delay; a tiny delay precedes "ten" and smile voice is replaced with wobble, which may indicate that "ten" is something of a tipping point where the modification of "like" to "four" is now officially beyond an acceptable margin of error (line 71). This is further supported by May's laughter-relevant deliberately-produced cough in line 72, signalling attention to a laughable (Jefferson, 2010), ratified by Lila's laughter (line 73). It is after this point that May, previously engaged with looking at her own phone screen, begins to orient to Lila and Em's counting (this is sustained as seen in image 9). Em them collaboratively continues the counting with the attentional "wait" in line 74 , followed by numbers eleven and twelve accompanied by pointing in which Em seems to specifically indicate photographs she is counting on the screen (see image 9). Lila produces laughter and "eleven" in overlap with Em's "twelve," showing she is back on board with counting, but lagging a bit to catch up (line 75). 


\section{Image 9 "Wait eleven" Line 75}

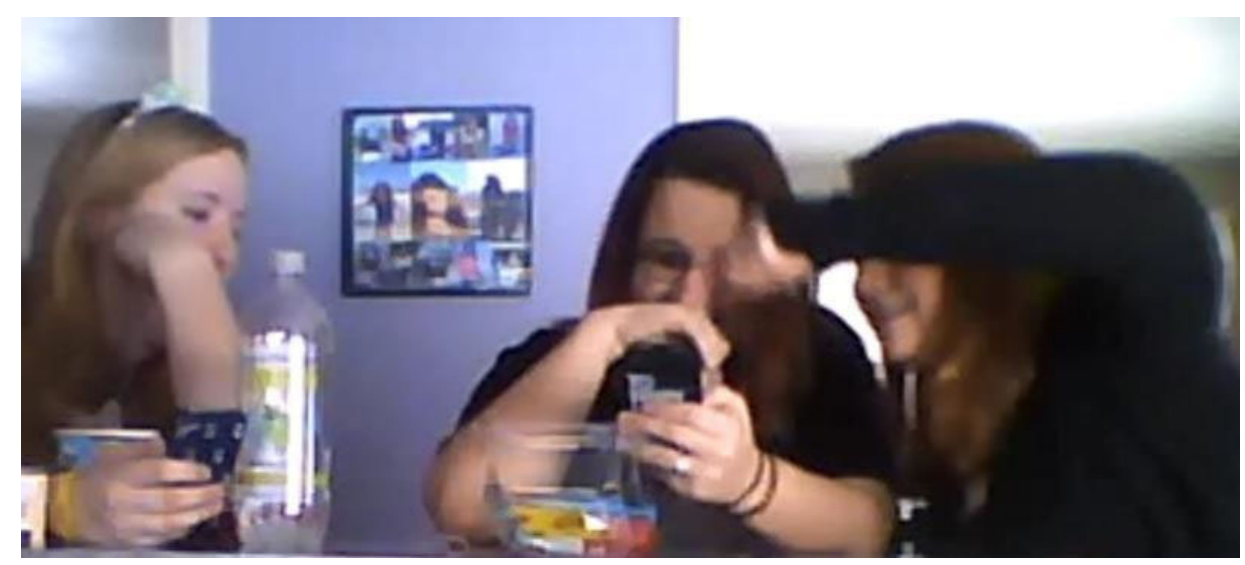

By the time the participants count to 13 selfies, Lila concedes that she has more selfies posted than she'd realized (lines 76-78). Her raised volume and sped-up rate of speech with repeated and rushed-through "alright"s comes across as both concession, and a request to end the sequence, a sort of "white flag," delivered definitively through the explicit formulation "you all win." As she produces repetition of "alright", Lila crosses her arms and leans away from Em, an embodied disengagement with the task at hand that calls a halt to the counting (image 10).

\section{Image 10 "Alright alright" Line 77}

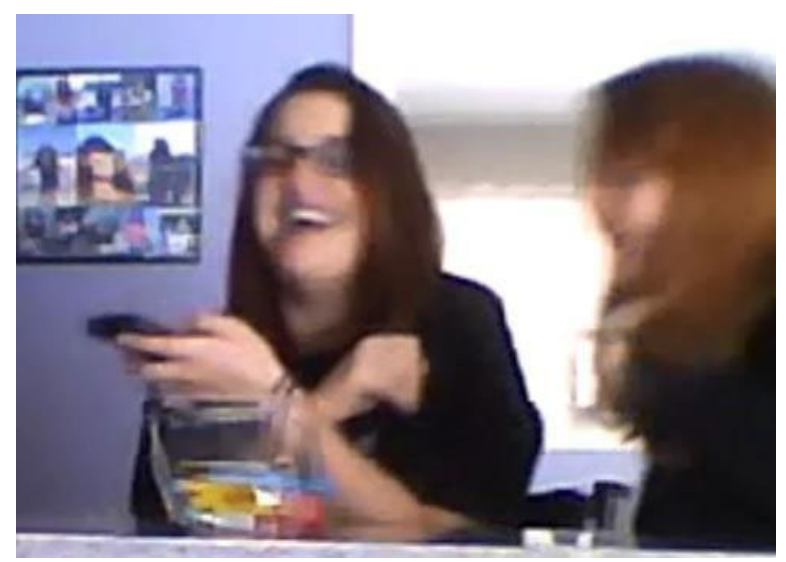

This formulation frames the talk as having been something of a competition, or test, in which Lila has come afoul, and Em's and May's reproaches of her behavior are confirmed as reasonable. Thus, Lila acknowledges what may constitute "a lot" or beyond some reasonable, modest, "normal" amount that she'd originally suggested. May goes on to explicitly note how far off base her assessment was, emphasizing that Lila posts a complainable and accountable number of selfies, which then prompts Lila to give an account for her behavior.

In the previous excerpt (Excerpt 3), numbers and enumeration were introduced to prove 
one's ordinariness on social media (though this backfires); in the next examples, numbers are used in a slightly different way that nonetheless bolster an account of one's ordinariness with regard to engaging with an online dating site. Excerpts 4 and 5 are taken from the same interaction featured in Excerpt 2. In both excerpts, Blake- - whose friend had signed him up for an account on an online dating website — seems to be doing some advice-seeking regarding whether to contact a woman who has messaged him. Blake repeats the number "one" to quantify a singular instance in which he was contacted by a woman through the website to whom he might consider responding.

\section{Excerpt 4 "There's one right now"}

$\begin{array}{lll}80 & \text { Ari: } & \text { any cuties? } \\ 81 & \text { Blake: } & \text { no. well there's one right now and } \\ & \text { I'm trying to decide if- if I } \\ 82 & & \text { should do anything about it? (.) } \\ 83 & \text { or just ignore her because I don't } \\ 84 & & \text { wanna lose [ ( ) } \\ 85 & \text { [ }<\text { feel like girls }> \\ 86 & \text { Ari: } & \text { that] go on online dating at our } \\ 87 & & \text { age? Are gonna be really we:ird= } \\ 88 & \text { Blake: =yeah [that's my thought too] } \\ 89 & \text { Ari: } & \text { [or already are really weird] } \\ 90 & & \end{array}$

In answer to a question from Ari about whether any of the women are messaging him through the online dating website he has ostensibly not created himself are "cuties" (line 80), Blake describes "one" about which he is trying to decide (lines 81-82). This is the heart of his story: whether to respond to the solicitation. However, it is occurring in the context of social media use presented as highly accountable. He has to be careful to avoid being seen as associated with the category "50 year old divorced woman," (see Excerpt 2) or other categories such as "weird girls," that the participants construct as strongly linked to online dating. Thus, emphasizing “one” presents Blake as someone who does not go looking for girls online, but who has happened upon a sort of exceptional case that might warrant action (e.g., contacting the woman). This allows Blake to be an ordinary person who, ultimately, does not ordinarily seek to engage in the use of online dating sites.

Since the initiation "I'm trying to decide" (line 82) receives no uptake, it ratifies 
Blake's tentative presentation of the trouble, and he follows it up by reintroducing the "one" girl with more emphasis on her anomalous status:

\section{Excerpt 5 "Literally only like one"}

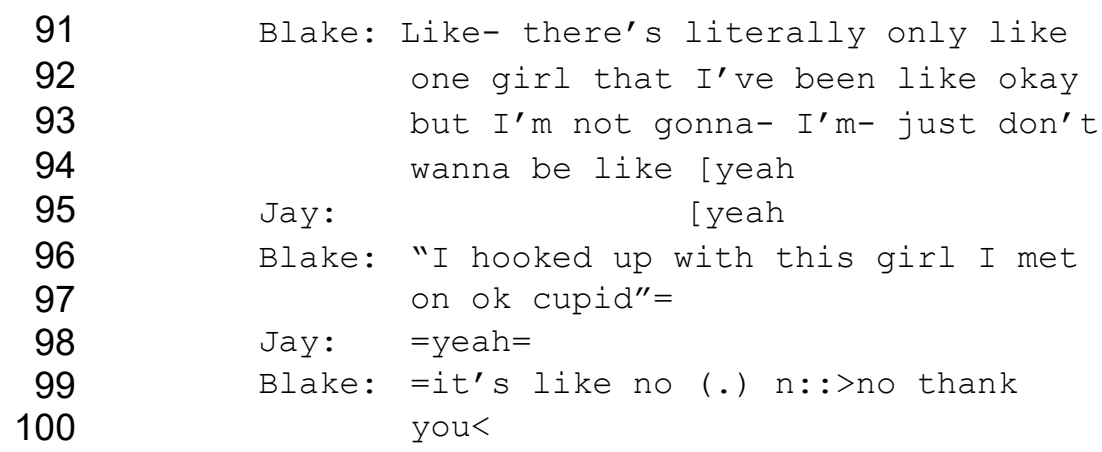

In Excerpt 5, Blake attempts to reintroduce his earlier turn and pursue advice, but this time he adds the words "literally," "only," and "like" leading up to the description of the "one girl" (lines 91-92) that he might be "okay" engaging with. This seems necessary, as he had previously agreed with the assessment that girls who use online dating sites are characterizable as weird (Excerpt 4). And the "literally" and "only" modify and upgrade the singularity of the "one," further emphasizing that interest in this girl is an exceptional case. The same undoing of Blake's interactional project of seeking advice happens as in Excerpt 4, however, and the contrastive account for a negative decision (not contacting the woman) is once more what gets the uptake, showing how accountable the social media activity is, and how it derails the trajectory of the advice-seeking action Blake is attempting.

In the next example, "time" is introduced as a quantifiable and accountable dimension of participating in a massively-multiplayer online role-playing game. In Excerpt 6, Megan and Lila have been discussing different forms of entertainment media when Megan initiates a new topic related to online gaming.

\section{Excerpt 6 "Eight to nine hours"}

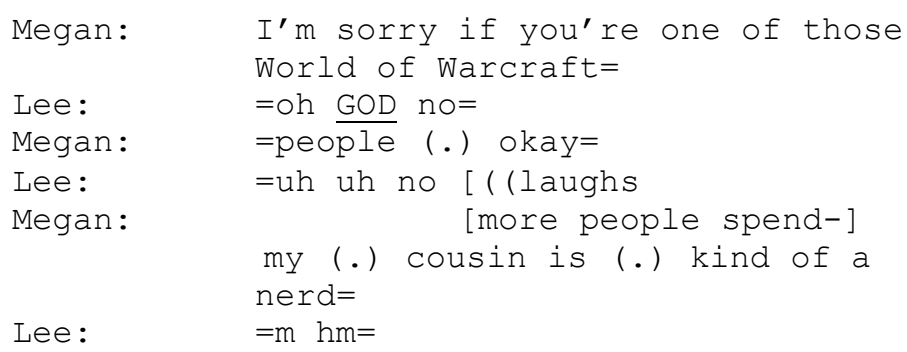




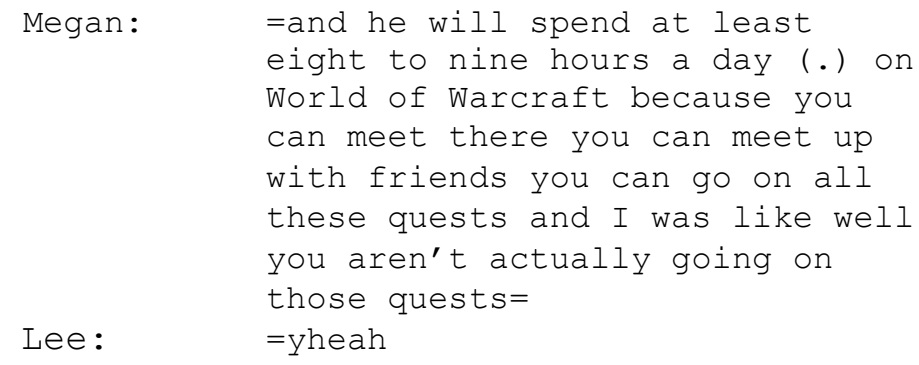

Megan offers a disclaimer in lines 101-102 with her hand out as if to sustain the interaction temporarily until this preface has been completed (perhaps suggesting she might have changed trajectory or her formulation of the next turn); she maintains this gesture as Lee says with emphasis, "oh god no" in line 103, raising her gaze upward and furrowing her brow in an expression of incredulity (see image 11).

\section{Image 11 “Oh god no" Line 103}

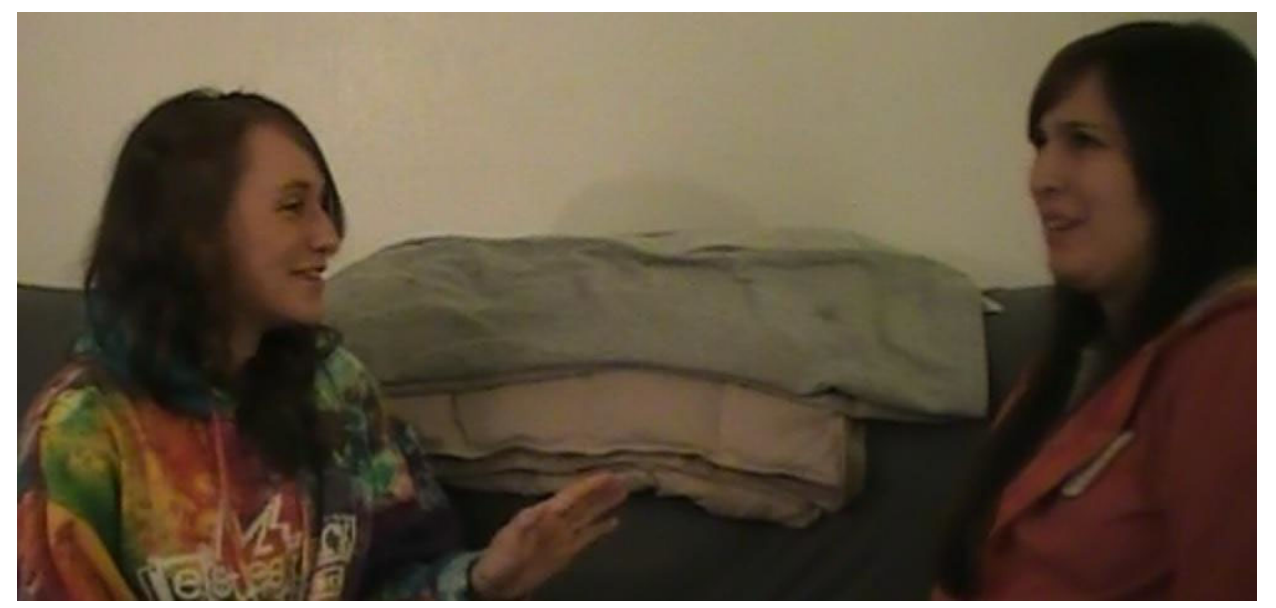

After ensuring Lee is not in the category "World of Warcraft people" (or people who play the massively-multiplayer online game "World of Warcraft"), Megan goes onto assess the gaming activities of the cousin she also categorizes as "kind of a nerd" (lines 107-108). Without making an explicit qualitative assessment, she implies something problematic in the quantity of time that her cousin spends online, formulating a range of "at least eight to nine hours a day" (lines 110111). As she produces "eight to nine" she makes a chopping gesture with her hand that marks the beat of each number (image 12) (see Rendle-Short, 2006), emphasizing the remarkability of these numbers. 


\section{Image 12 "Eight to nine" Line 111}

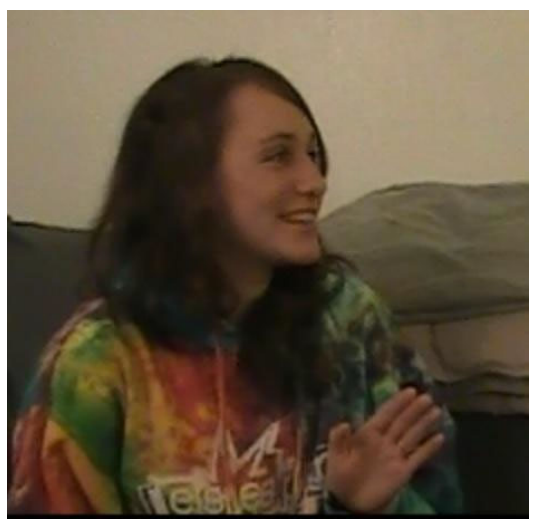

This range constitutes a long time frame for almost any activity people would generally class as a hobby; rather, it cues associations with a typical workday. Thus, not only is it a long amount of time, it is framed as a possible replacement for "productive" time as well. The emphasis on the the time's "pointlessness" is highlighted by Megan describing (with reported speech, or possibly a reported hypothetical thought) that "you [the cousin] aren't actually going on those quests" (lines 116-117). This, then, is the upshot of the time frame: spending any amount of time on something that is not "really happening" is exacerbated by spending an excessive amount of time that most people would devote to a workday. Though Megan's cousin's age is not mentioned and he may be too young to work, or young enough that most of his time can be spent in leisure, one would still expect he has to go to school now and again.

A related practice to these sorts of quantifications involved uses of more vaguely quantifying terms that functioned as extreme case formulations, proposing the ordinariness of one's behavior in contrast to what might be "excessive," but in an inexact way. Space does not permit a detailed analysis of all such cases here, but examples included for instance "I try not to be constantly on my cell phone, I try not to text, um, and I try not to be constantly on Facebook," "it's literally every text he sends like what are you saying," and "every single thing he posts is like look at me feel sorry for me." In these and other examples, participants' communication and social media technology behavior flags up unreasonable implications in terms of "how much," "how often," "how many," and so forth. This is an extension of managing motivation, as participants treat amounts of engagement with technological objects as indicative of stake. In 
other words, you cannot just be innocently participating--there is such a thing as "too much" caring about the online activity, and playing the numbers game is one way participants seek to head-off the critique that they are overly invested in social media. By participating in these time references (Raymond \& White, 2017) and scaling activities (Bilmes, 2010), participants orient to the possibility that their descriptions of their technology use may be met with actions such as negative identity assessments (e.g., "desperate" or "attention-seeking"). Thus the measurements of a certain activity are treated as relevant to managing courses of action. Participants must measure their quantity or how much they use new communication technologies and social media to present their usage as typical. In the next section, we spotlight how participants orient to and account for their technology use as relevant to assessments of identity.

\subsection{Identifying Investments}

In the previous sections we discussed how, while norms of technology use provide a rich and accessible resource for evaluating and understanding participants' social actions, they also come with possible troubles that may make them accountable. Participants orient to this possibility by introducing their usage as ordinary and unproblematic, and by attempting to combat various threats to this portrayal as they arise. The upshot of this negotiation is that participants treat social media usage as having implications for identity. In other words, accountability is not just implicated by why and how they use social media, but who they appear to be by doing so, and whether this "who" is just a regular person, and how this features in their situated actions. In this section, we inspect different ways in which participants display members' analyses and assessments of their own, one another's, and non-present third parties' technology use in a way that specifically focuses on identity implications and assessments. In

Excerpt 7, Lila is providing an account for why she has so many selfies posted on Instagram.

\section{Excerpt 7 "Attractive little punk boys like my photos"}

Lila:

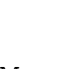

May :

Lila:

Em:
[Ins] tagram is $\underline{\mathrm{fu}}: \mathrm{n}$,

attractive little punk boys

like my photos.

( (sniff))

['I'm okay (with that ${ }^{\circ}$ )]

[but they're] like people

you're never gonna mee: $t=$ 


\begin{tabular}{|c|c|c|}
\hline 126 & Lila: & $=\operatorname{sh}:::=$ \\
\hline 127 & Em: & $=$ why does it matter what \\
\hline 128 & & they think \\
\hline 129 & Lila: & (when you're sad) $d_{\uparrow o n}{ }^{\prime} t$ you \\
\hline 130 & & like to have a boy call you \\
\hline 31 & & pretty? \\
\hline 132 & & $(0.8)$ \\
\hline 133 & May: & $((\operatorname{sniff}))$ \\
\hline 134 & & (.) \\
\hline 135 & Em: & but (.) they're (.) people \\
\hline 136 & & $\mathrm{kn} \uparrow \mathrm{OW}$ (.) usually= \\
\hline 137 & Lila: & $=\mathrm{m}$ hm I don't care if they \\
\hline 38 & & know me I mean I don't like \\
\hline 0 & & half the people I know (.) \\
\hline & & uh huh huh= \\
\hline
\end{tabular}

Lila returns to the theme of the ordinariness of her social media usage by attempting to describe it as a form of harmless "fun" (lines 119-121). By treating it as trivial, Lila defends against prior assessments of her conduct as complainable (e.g. that she takes and posts an accountable number of selfies). However, her attempts to renormalize are rejected, as her identity (built through positioning her as someone who regularly engages in this selfie-taking selfie-posting behavior) is constructed as either too, or mistakenly, invested. Em disaligns with Lila's accounts: the "likes" Lila receives are rejected because (1) the people liking them are only known from online modalities alone (i.e., not face-to-face interaction); (2) she'll never meet them (line 125); (3) it shouldn't matter what they think (lines 127-128); and (4) it's better to be complimented by people one "knows" (presumably offline, "in real life") (lines 135-136). By constructing Lila's social media engagement as misinvested, Em questions the affective basis Lila has constructed as an account, replacing a trivial self-esteem boost with a mistaken attempt to seek affirmation in the wrong place. In doing so, Em suggests Lila's accounts are insufficient, and that there is still something problematic about her avowed motivations for what she does online. This positions Lila as potentially a person with low self-esteem, who is desperate for attention, or who is pleased by trivial compliments.

The next example shows a more explicit articulation of an assessment of a non-present third party's behavior online, and how this can be read problematically by others. Bea is describing how her mother is attempting to get Bea to befriend the sister of a roommate to a mutually-known party (“his," line 143). 


\section{Excerpt 8 "You're a slut"}

\begin{tabular}{|c|c|c|}
\hline 141 & Bea: & my mom is like (.) trying to get \\
\hline 142 & & me to be buddy buddy with: one of \\
\hline 143 & & his <roommate's sisters> which is \\
\hline 144 & & like a year older than me, and \\
\hline 145 & & literally? I looked at her \\
\hline 146 & & facebook and I'm like scared \\
\hline 147 & & (f)her (.) all of her pictures are \\
\hline 148 & & just like her tits are like out \\
\hline 149 & & and like- it's like- you're $\overline{\mathrm{a} s}-$ \\
\hline 150 & & like- l: : =>I don't even $<$ KNOW \\
\hline 151 & & it's just [gro:ss \\
\hline 152 & Cat: & [you're] a slut. \\
\hline 153 & Bea: & it's gross $=$ \\
\hline 154 & Cat: & $=$ you're a slut $=$ \\
\hline 155 & Bea: & $=i t^{\prime} \mathrm{s}$ like every single picture \\
\hline
\end{tabular}

In Excerpt 8, Bea launches a complaint featuring a description of another's social media usage, this time on Facebook (lines 145-150). She presents viewing social media as an ordinary way in which people may gain insight into another's personality. Her description of her reaction as "scared (f)her" is ambiguous in that it could be heard as "scared of her" or "scared for her" (lines 146-147). Either way, the reading is negative, projecting that she is about to describe something accountable about what the person posts on Facebook. She goes onto describe the problem as "all of her pictures are just like her tits are like out" (lines 147-148), suggesting the woman posts a lot of photographs (with the extreme case formulation "all") in which her breasts are prominent (it is unlikely they are completely visible, as this would violate Facebook's policy and likely be removed). Thus, the description is not literal, but emotive, meant to convey a sort of person who is representing themselves in a risqué, unreasonable, objectionable manner.

Bea leads several times into an upshot of how to characterize the behavior, but repairs to, and repeats, "gross" instead (lines 149-151), choosing to emphasize her affective reaction rather than to label an identity for the other. She presents a strong negative stance toward the woman's self- presentation on social media, implicating norms about what is and is not acceptable. While the stance is not formulated explicitly, it seems likely that Cat's formulation "you're a slut" (spoken as though to the non-present woman) in line 152, and repeated in line 154, is probably a completion of where Bea was going, read off the sibilant and liquid particles produced in the turn “you're a s- like- 1::" (lines 149-150). By selecting the category "slut," Cat (and implicitly Bea) 
identify the non-present woman as problematic in orientation to her social media usage, specifically her presentation of self online, therefore portraying her as potentially problematic as a person. The problem in this case is a stake in portraying a certain kind of sexualized identity that is being presented as at odds with reasonable behavior. Thus, as in the previous example, participants read social media usage for "clues" about others' investments in it, and draw out implications for their identity in order to accomplish actions: to categorize, label, and assess. To present an ordinary, normal character, participants identify for themselves and others who they appear to be when using new communication technologies and social media. This constructs norms for how people should "ordinarily" conduct themselves online, suggesting that those who do not open themselves up to harsh negative assessments. Examples such as these show how participants orient to communication technologies as relevant windows into others' identities and as resources for locally and cultural constructing the morality of selves and others.

\section{Discussion}

Our analysis supports several practices through which participants may negotiate the accountability of communication technologies during the turn-by-turn dynamics of ordinary conversation. Participants draw on aspects of new communication technologies--including the devices themselves, access to social media platforms, and talk about norms of usage of either--to accomplish social actions. There are many reasons why this may be the case, for example, that mobile phones are ready-to-hand and therefore a visible reminder of relevance; that new communication technologies are ubiquitous and generate a steady stream of metadiscourse, making them more easily topicalized; and so forth (see DiDomenico \& Boase, 2013; Humphreys, 2010; Ling, 2008; Turkle, 2015a).

In our analyses we show how participants use certain descriptions, embodied performances, category references, and other activities in service of certain discursive practices. For example, in excerpt 1, the ordinariness of Lila's selfie-taking is produced through slang, embodied enactment, object manipulation, contrastive descriptions, and so forth, to accomplish a complaint that repositions her own behavior as unremarkable and manages her motivations for 
engaging in taking and posting selfies. These activities and their judgments--whether they are reasonable or not--are treated as relevant and consequential to the actions participants are trying to get done, and are dealt with along the way to navigate possible trouble.

One implication of this research is how we understand the intersection of identity work and mundane communication about technology use. When Sacks (1984) described "doing being ordinary," he was highlighting the ways in which ordinariness is a social and interactional achievement. Here "being" suggests that part of this achievement is to make the ordinariness seem natural, effortless, artless, and neutral. But the "doing" aspect subverts the assumption, showing that even what looks like "being" is still a social action. Our analysis shows how this holds true with regard to new domains, wherein participants display some of the interactional work they do in order to come across as ordinary. That this work is more visible suggests there is still contestation around the role of communication technologies in our lives. Our analysis offers a snapshot of what negotiating their meaning looks like in everyday practice.

We have drawn on a certain flavor of discourse analysis, and aspects of embodied and conversation analysis, to examine the multiple ways in which participants use technological objects and topicalize their affordances to accomplish situated activity. By attending to pragmatic, discursive psychological, and communicational functions of talk, we show how participants construct the meaning of these particular objects and topics; by grounding these in participants embodied, sequential, and action-oriented conduct, we show these practices unfold in service of doing things in interaction. This analysis sheds light on accountability in conversations about technology use (Buttny, 1993), specifically how increasingly technologically-rich features of social life may themselves be treated as accountable by participants in interaction. The resources provided by portable media devices and their communicative affordances are ever available and dependable for integrating into the social actions that make up our face-to-face encounters. But their ubiquity has not "normalized" them in the sense that their use is unproblematic. Instead, it seems certain boundaries of ordinariness are even more salient in the turn by turn dynamics of conversation. By examining how people 
produce, retrieve, or challenge their "ordinary" status in such situations, we catch a glimpse of cultural norms as they are being worked out, on the ground. This has implications for how mundane morality is constructed around the way we choose to interface with new and emerging technologies in everyday life.

The impact of evolving ideologies that people hold about different media-both new and old —also seems relevant to these findings. Gershon $(2009,2017)$ has discussed the role of recent communication technology in people's greater reflexive awareness of how the design of any specific medium (including its affordances) structures their communication as well as how such communication should be interpreted. Such media ideologies and media practices are, according to Gershon, continually shaped by and compared with our ideological understandings for all other channels we have available for communication, including face-to-face interaction.

\section{Conclusion}

This paper has offered a naturalistic take on how participants manage the accountability of technology use during conversation, including shoed how such accountability arises in topicalizations, how the stakes surrounding social behavior can become problematic, and the identity-related reasons that bolster why each of these matter at all for human sociality. We have illustrated several practices through which participants dealt with these aspects of accountability within broader conversational projects: first, managing their own motivations with regard to using communication technologies and social media; second, by calibrating the quantities of their usage in response to challenges (or potential challenges); and third, by identifying relationships between usage and identity categories that reaffirmed the relevance of investment and the need for continuing to account for it. In doing so, participants built stances that resonate-in ways that reflect, and construct--with larger social norms. Through close examination of the specific linguistic and embodied practices that make up the turn-by-turn dynamics of interaction, this paper has developed a empirically grounded account of how participants constitutes the ordinary and the problematic in the social life of technology use. 


\section{References}

Akar, E., \& Topçu, B. (2011). An examination of the factors influencing consumers' attitudes toward social media marketing. Journal of Internet Commerce, 10(1), 35-67.

Arminen, I. (2005). Sequential order and sequence structure: the case of incommensurable studies on mobile phone calls. Discourse Studies, 7(6), 649-662.

Arminen, I., Licoppe, C., \& Spagnolli, A. (2016). Respecifying Mediated Interaction. Research on Language and Social Interaction, 49(4), 290-309.

Bargh, J. A., \& McKenna, K. Y. (2004). The Internet and social life. Annu. Rev. Psychol., 55, 573-590.

Beck, J. (2016, June 14). Ignoring people for phones is the new normal: A study looks at how phone snubbing--"phubbing"--becomes socially acceptable. The Atlantic. Retrieved from https://www.theatlantic.com/technology/archive/2016/06/ignoring-people-for-phones-isthe-new-normal-phubbing-study/486845/

Bennett, W. L., \& Segerberg, A. (2011). Digital media and the personalization of collective action: Social technology and the organization of protests against the global economic crisis. Information, Communication \& Society,14(6), 770-799.

Segerberg, A., \& Bennett, W. L. (2011). Social media and the organization of collective action: Using Twitter to explore the ecologies of two climate change protests. The Communication Review, 14(3), 197-215.

Barker, J. (2008). Playing with publics: Technology, talk and sociability in Indonesia. Language \& Communication, 28(2), 127-142.

Boyd, D. (2010). Streams of content, limited attention: The flow of information through social media. Educause Review, 45(5), 26.

Barry Brown, Moira McGregor and Donald McMillan. 2014. 100 Days of iPhone Use: Understanding the Details of Mobile Device Use. In Proceedings of the 16th International Conference on Human-computer Interaction with Mobile Devices \& 
Services, ACM, 223- 232.

Bilmes, J. (2010). Scaling as an aspect of formulation in verbal interaction. In Language learning and socialization through conversations (pp. 3-9). Osaka, Japan: Center for Human Activitiy Theory, Kansai University.

Buttny, R. (1993). Social accountability in communication. Sage.

Cameron, D. (2001). Working with spoken discourse. London: Sage.

Carbaugh, D., Berry, M., \& Nurmikari-Berry, M. (2006). Coding personhood through cultural terms and practices: Silence and quietude as a Finnish "natural way of being". Journal of Language and Social Psychology, 25(3), 203-220.

DiDomenico, S. M. \& Boase, J. (2013). Bringing mobiles into the conversation: Applying a conversation analytic approach to the study of mobiles in co-present interaction. In D. Tannen \& A. Trester (Eds.), Discourse 2.0: Language and new media (pp. 119-131). Washington, DC: Georgetown University Press.

D’Urso, S. C. (2009). The past, present, and future of human communication and technology research: An introduction. Journal of Computer-Mediated Communication, 14(3), 708713.

Ehrlich, S., \& Romaniuk, T. (2014). Discourse analysis. In P. R. J. Podesva \& D. D. Sharma (Eds.), Research methods in linguistics (pp. 460-493). Cambridge, England: Cambridge University Press

Gangadharbatla, H. (2008). Facebook me: Collective self-esteem, need to belong, and internet self-efficacy as predictors of the iGeneration's attitudes toward social networking sites. Journal of Interactive Advertising, 8(2), 5-15.

Garfinkel, H. (1967). Studies in ethnomethodology. Englewood Cliffs, NJ: Prentice-Hall.

Gershon, I. (2010). Media ideologies: An introduction. Journal of Linguistic Anthropology, 20(2), 283-293.

Gershon, I. (2017). Language and the Newness of Media. Annual Review of Anthropology, (0).

Gibson, J. J. (1977). The theory of affordances. In R. E. Shaw \& J. Bransford (Eds.), Perceiving, 
acting, and knowing: Toward an ecological psychology (pp. 67-82). Hillsdale, NJ: Lawrence Erlbaum.

Goffman, E. (1959). The presentation of self in everyday life. New York: Doubleday Anchor.

Goffman, E. (1967). On facework: An analysis of ritual elements in social interaction. In: Interaction Ritual (pp. 4 - 22). Garden City, NY: Anchor Books.

Goldsmith, D. J., \& Fitch, K. (1997). The normative context of advice as social support. Human communication research, 23(4), 454-476.

Goodwin, C. (2000). Action and embodiment within situated human interaction. Journal of pragmatics, 32(10), 1489-1522.

Gordon, C. (2006). Reshaping prior text, reshaping identities. Text and Talk, 26(4/5), 545.

Haddington, P. \& Rauniomaa, M. (2011). Technologies, multitasking and driving: attending to and preparing for a mobile phone conversation in the car. Human Communication Research 37(2): 223-254.

Herring, S. C. (2015). "New Frontiers in Interactive Multimodal Communication.” In The Routledge Handbook of Language and Digital Communication. In:, ed. by A. Alexandra Georgapoulou and T.Tereza Spilloti (Eds.), The Routledge Handbook of Language and Digital Communication, (p., 398-402). London: Routledge.

Kapidzic, S., \& Herring, S. C. (2014). Race, gender, and self-presentation in teen profile photographs. In J. D. Wright(eds.), International encyclopedia of social and behavioral sciences. Oxford: Elsevier.

Hampton, K. (2012). Social media as community. The New York Times. Retrieved from https://www.nytimes.com/roomfordebate/2012/02/12/the-advantages-and-disadvantagesof-living-alone/social-media-as-community? mcubz=1

Hickerson, A., \& Kothari, A. (2016). Learning in Public Faculty and Student Opinions About Social Media in the Classroom. Journalism \& Mass Communication Educator.

Humphreys, L. (2005). Cellphones in public: social interactions in a wireless era. New Media \& Society, 7(6), 810-833. 
Humphreys, L. (2010). Mobile social networks and urban public space. New Media \& Society, 12(5), 763-778.

Jaffe, A. (2009). Stance: sociolinguistic perspectives. OUP USA.

Jefferson, G. (1984). Transcription notation. In J. M. Atkinson \& J. Heritage (Eds.), Structures of social action: Studies in conversation analysis (pp. ix-xi). Cambridge, UK: Cambridge University Press.

Jefferson, G. (1988). On the sequential organization of troubles-talk in ordinary conversation. Social problems, 35(4), 418-441.

Jefferson, G. (2004). At first I thought”: a normalizing device for extraordinary events. Conversation analysis: Studies from the first generation (pp. 131-67). Amsterdam: John Benjamins.

Jefferson, G. (2010). Sometimes a frog in your throat is just a frog in your throat: Gutturals as (sometimes) laughter-implicative. Journal of Pragmatics, 42(6), 1476-1484.

Jung, T., Youn, H., \& McClung, S. (2007). Motivations and self-presentation strategies on Korean-based "Cyworld" weblog format personal homepages. CyberPsychology \& Behavior, 10(1), 24-31.

Kietzmann, J. H., Hermkens, K., McCarthy, I. P., \& Silvestre, B. S. (2011). Social media? Get serious! Understanding the functional building blocks of social media. Business Horizons, 54(3), 241-251.

Kennedy, H., D. Elgesem, and C. Miguel (2015) “On fairness: User perspectives on social media data mining." Convergence: The International Journal of Research into New Media Technologies.

Laurier, E., Brown, B., \& McGregor, M. (2016). Mediated pedestrian mobility: Walking and the map app. Mobilities, 11(1), 117-134.

Laursen, D. (2012). Sequential organization of text messages and mobile phone calls in interconnected communication sequences. Discourse \& Communication, 6(1), 83-99.

Lenhart, A., Ling, R., Campbell, S., \& Purcell, K. (2010). Teens and mobile phones. Retrieved 
from https://pewinternet.org/reports/2010/ teens-and-mobile-phones.aspx

Licoppe, C. (2004). 'Connected'presence: the emergence of a new repertoire for managing social relationships in a changing communication technoscape. Environment and planning D: Society and space, 22(1), 135-156.

Lievrouw L (2014). Materiality and media in communication and technology studies: an unfinished project. In: Gillespie T, Boczkowski P and Foot K (eds) Media Technologies: Essays on Communication, Materiality, and Society. Cambridge, MA: The MIT Press, pp. $21-51$.

Lievrouw, L. A., Bucy, E. P., Finn, T. A., Frindte, W., Gershon, R. A., Haythornthwaite, C., .et al. (2001). Bridging the subdisciplines: An overview of communication and technology research. Annals of the International Communication Association, 24(1), 271-296.

Ling, R. (2004). The mobile connection: The cell phone's impact on society. Morgan Kaufmann.

Ling, R. (2008). New tech, new ties: How mobile communication is reshaping social cohesion. Cambridge, MA: MIT Press.

Ling, R. \& Baron, N. (2013). Mobile phone communication. In S. C. Herring, D. Stein, \& T. Virtanen. Pragmatics of computer-mediated communication (pp. 191-216). Berlin, Germany: Walter de Gruyter GmbH.

Ling, R. \& L. Haddon (2003). Mobile telephony, mobility, and the coordination of everyday life, in J. Katz (ed.). Machines That Becomes Us, pp. 245 - 266. New Brunswick, NJ: Transaction Publishers.

Ling, R., \& Yttri, B. (1999). Nobody sits at home and waits for the telephone to ring: Micro and hyper-coordination through the use of the mobile telephone. Telenor Forskning og Utvikling, FoU Rapport, 30(99).

Lu, W.. \& Hampton, K. (2017). Beyond the power of networks: Differentiating network structure from social media affordances for perceived social support. New Media \& Society, 19(6), 861-879.

Niemelä, M. (2010). The reporting space in conversational storytelling: Orchestrating all 
semiotic channels for taking a stance. Journal of Pragmatics, 42(12), 3258-3270.

Ong, E. Y., Ang, R. P., Ho, J. C., Lim, J. C., Goh, D. H., Lee, C. S., \& Chua, A. Y. (2011). Narcissism, extraversion and adolescents' self-presentation on Facebook. Personality and Individual Differences, 50(2), 180-185.

Oppenheimer, M. (2014, January 17). Technology is not driving us apart after all. The New York Times Magazine. Retrieved from https://www.nytimes.com/2014/01/19/magazine/technology-is-not-driving-us-apart-afterall.html?_r=0

Pearce, K. E., \& Vitak, J. (2015). Performing honor online: The affordances of social media for surveillance and impression management in an honor culture. New Media \& Society, 1461444815600279.

Pomerantz, A. (1986). Extreme case formulations: A way of legitimizing claims. Human studies, 9(2), 219-229.

Potter, J. (2003). Discourse analysis and discursive psychology. In P. M. Camic, J. E. Rhodes, \& L. Yardley (Eds.), Qualitative research in psychology: Expanding perspectives in methodology and design (pp. 73-94). Washington, DC, US: American Psychological Association.

Potter, J., \& Hepburn, A. (2007). Discursive psychology: mind and reality in practice. In A. Weatherall, B. Watson \& C. Gallois (Eds.), Language, discourse and social psychology (pp. 160-181). New York: Palgrave MacMillan.

Raclaw, J., Robles, J. S., \& DiDomenico, S. M. (2016). Providing epistemic support for assessments through mobile-supported sharing activities. Research on Language and Social Interaction, 49(4), 362-379.

Raymond, C. W., \& White, A. E. C. (2017). Time reference in the service of social action. Social Psychology Quarterly, 80(2), 109-131.

Rendle-Short, J. (2006). The academic presentation: Situated talk in action. Farnham: Ashgate Publishing, Ltd. 
Rivière, C. A., Licoppe, C., \& Morel, J. (2015). Gay Casual Hookups on the Mobile Application Grindr. Réseaux, (1), 153-186.

Roberts, J. A., \& David, M. E. (2016). My life has become a major distraction from my cell phone: Partner phubbing and relationship satisfaction among romantic partners. Computers in Human Behavior, 54, 134-141.

Sacks, H. (1984). On doing being ordinary. In: Atkinson and Heritage (Eds). Structures of social action. Cambridge University Press, New York.

Sacks, H. (1986). On the Analyzability of Stories by Children. In Gumperz and Hymes (Eds.). Directions in sociolinguistics: The ethnography of communication (pp. 325-45). NY: Basil Blackwell Inc.

Sacks, H. (1989). Lecture three: The correction-invitation device. Human Studies, 12, 247-252.

Sacks, H. (1992). Lectures on conversation (Vol. 2). Oxford, MA: Blackwell.

Schegloff, E. A. (2007). Sequence organization in interaction: Volume 1: A primer in conversation analysis (Vol. 1). Cambridge: Cambridge University Press.

Schutz, A. (1967). The phenomenology of the social world. Northwestern University Press.

Selting, M. (2010). Affectivity in conversational storytelling. Pragmatics, 20(2), 229-277.

Tannen, D., \& Trester, A. M. (Eds.). (2013). Discourse 2.0: language and new media. Georgetown University Press.

Taylor, T. J. (2016). Folk-linguistic fictions and the explananda of the language sciences. New Ideas in Psychology, 42, 7-13.

Tidwell, L. C., \& Walther, J. B. (2002). Computer-mediated communication effects on disclosure, impressions, and interpersonal evaluations: Getting to know one another a bit at a time. Human Communication Research, 28(3), 317-348.

Tiidenberg, K. (2014). Bringing sexy back: Reclaiming the body aesthetic via self-shooting. Cyberpsychology: Journal of Psychosocial Research on Cyberspace, 8(1), 1-15.

Tiidenberg, K., \& Gómez Cruz, E. (2015). Selfies, image and the re-making of the body. Body \& Society, 21(4), 77-102. 
Tracy, K. (2001). Discourse analysis in communication. In D. Schiffrin, D. Tannen \& H. E. Hamilton (Eds.), The handbook of discourse analysis (pp. 725-749). London: Wiley Blackwell.

Turkle, S. (2015a). Reclaiming conversation: The power of talk in a digital age. Penguin.

Turkle, S. (2015b). Stop googling. Let's talk. The New York Times. Retrieved from http://www. nytimes. com/2015/09/27/opinion/sunday/stop-googling-lets-talk. html.

Utz, S., \& Krämer, N. C. (2015). The privacy paradox on social network sites revisited: The role of individual characteristics and group norms. Cyberpsychology: Journal of Psychosocial Research on Cyberspace, 3(2).

Walther, J. B., Loh, T., \& Granka, L. (2005). Let me count the ways the interchange of verbal and nonverbal cues in computer-mediated and face-to-face affinity. Journal of Language and Social Psychology, 24(1), 36-65.

Walther, J. B., Gay, G., \& Hancock, J. T. (2005). How do communication and technology researchers study the internet? Journal of Communication, 55(3), 632-657.

Weixu, L. \& Hampton, K. (2017). Beyond the power of networks: Differentiating network structure from social media affordances for perceived social support. New Media \& Society, 19(6), p. 861-879.

Westerman, D., Daniel, E. S., \& Bowman, N. D. (2016). Learned risks and experienced rewards: Exploring the potential sources of students' attitudes toward social media and face-to-face communication. The Internet and Higher Education, 31, 52-57. 